\title{
Synthesis of New Cationic Metalloporphyrins and Heterodimer Formation with Anionic Metallophthalocyanines
}

\author{
Marcela G. Ribeiro and Gianluca C. Azzellini*
}

Instituto de Química, Universidade de São Paulo, Av. Lineu Prestes, 748, 05508-900, São Paulo - SP, Brazil

\begin{abstract}
Existe grande interesse no estudo de heterodímeros constituídos por metaloporfirinas e ftalocianinas de carga oposta, uma vez que estes sistemas são modelos do special pair da fotossíntese e dispositivos moleculares promissores para a transferência de elétrons unidirecional. Neste trabalho foram sintetizadas novas metaloporfirinas catiônicas, e investigada a formação de heteroagregados com metaloftalocianinas aniônicas em DMSO. Estes novos derivados porfirínicos catiônicos apresentam grupos benzílicos ligados aos nitrogênios piridínicos da tetra-(piridil)porfirina ( $\left.\mathrm{H}_{2} \mathrm{TPyP}\right)$, resultando em compostos que são mais hidrofóbicos e que apresentam sistemas $\pi$ adicionais em relação aos ligantes tetra-(metilpiridínio)porfirina $\left(\mathrm{H}_{2} \mathrm{TMPyP}\right)$ e tetra-(trimetilaminofenil)porfirina ( $\mathrm{H}_{2}$ TAPP). Observou-se que a estequiometria dos agregados formados e os valores de constante de associação entre as porfirinas catiônicas e as ftalocianinas aniônicas são dependentes do metal coordenado a ambos os macrociclos. As Zn(II)porfirinas formam em solução preferencialmente o agregado de estequiometria 1:1 (porfirina:ftalocianina) no meio reacional, enquanto que no caso das Pd(II)porfirinas pode ocorrer a formação de agregados 1:1 ou 1:2 (porfirina:ftalocianina). Os valores de $\mathrm{K}_{\mathrm{pI}}$, por sua vez, são sempre maiores para os agregados formados com as ftalocianinas de $\mathrm{Cu}$ (II), sendo este comportamento relacionado com a menor distorção para fora do plano da ligação $\mathrm{Cu}-\mathrm{N}$ comparada com a ligação Ni-N em decorrência da ligação axial de uma molécula de DMSO ao íon metálico coordenado à ftalocianina. Os valores de $\mathrm{K}_{\mathrm{PI}}$ também são menores para os heterodímeros formados com as porfirinas que apresentam os meso-susbtituintes benzílicos mais volumosos, em função da disposição angular dos mesmos em relação ao plano do anel porfirínico que provoca um maior impedimento estérico. Estes resultados demonstram que a associação entre macrociclos tetrapirrólicos pode ser controlada através de vários fatores estruturais. Estes fatores também podem conduzir a diferentes propriedades fotofísicas destes heteroagregados; estudos neste sentido estão em andamento.
\end{abstract}

There is great interest in the investigation of heterodimers formed by metalloporphyrins and metallophthalocyanines grafted with oppositely charged substituents, since these systems are models of the photosynthetic special pair and promising unidirectional electron transfer molecular devices. In the present study new cationic metalloporphyrin derivatives were synthesized and their association with anionic metallophthalocyanines forming heteroaggregates, investigated. These new cationic porphyrins derivatives show benzylic groups bound to the pyridyl nitrogen atoms of tetra(pyridyl)porphyrin (TPyP), resulting in additional $\pi$ systems and more hydrophobic compounds if compared with tetra-(methylpiridinium)porphyrin $\left(\mathrm{H}_{2} \mathrm{TMPyP}\right)$ and tetra-(trimethylaminophenyl)porphyrin ( $\left.\mathrm{H}_{2} \mathrm{TAPP}\right)$ ligands. It could be observed that both stoichiometry and association constants between cationic porphyrins and anionic phthalocyanines depend on the metal complexed to the macrocycles. $\mathrm{Zn}(\mathrm{II})$ porphyrins form preferentially aggregates of 1:1 stoichiometry (porphyrin:phthalocyanine), but when the porphyrin is coordinated to $\operatorname{Pd}($ II) $1: 1$ and 1:2 (porphyrin:phthalocyanine) aggregates are present in solution. The $\mathrm{K}_{\mathrm{PI}}$ values are always higher for the heterodimers ZnPorphyrin/CuPhthalocyanine; this behavior is related to the less pronounced out-of-plane distortion of $\mathrm{Cu}-\mathrm{N}$ compared to Ni-N binding, as a result of axial ligation of a DMSO molecule to the metal ion inserted into the macrocycle core. The $\mathrm{K}_{\mathrm{PI}}$ values are lower for the heterodimers containing the porphyrins that present the larger benzylic meso-substituent, due to the steric hindrance caused by these groups. These results show that many structural features can control the association between tetrapyrrolic macrocycles. Not only the association can be modulated by these structural factors, but also different photophysical properties should be displayed by these aggregates, and studies in this direction are under way.

Keywords: photosynthetic special pair models, cationic porphyrins, heterodimer

\footnotetext{
* e-mail: gcazzell@iq.usp.br
} 


\section{Introduction}

Macrocyclic tetrapyrroles, like porphyrin derivatives, occur biologically in many enzymes, ${ }^{1}$ in heme compounds ${ }^{2}$ and in photosynthetic protein as chlorophyll. ${ }^{3}$ Particularly in this case, two chlorophylls adopt a face-to-face conformation to form the so-called special pair, the efficient primary electron-donor in the photosynthetic apparatus. It is known that the cofacial arrangement of chlorophylls is a very important feature, because photosynthetic electron transfer process is a function of macrocycle separation and orientation. ${ }^{4}$

The complexity of this process has prompted numerous studies of pairing donor-acceptor molecules to mimic the photosynthetic system. These molecules have been joined through covalent alkyl chains, ${ }^{5}$ peptide bond, hydrogen bond, ${ }^{6}$ rigid spacers, ${ }^{7}$ self-assembled via metal-ligands, ${ }^{8}$ or more recently, through ion pairing formed by association of molecules grafted with oppositely charged substituents. ${ }^{9,10}$

Synthetic macrocycles such as porphyrins, and structurally similar phthalocyanines share many of the characteristics of the naturally occurring porphyrin-like systems. Spontaneous aggregation between porphyrins and phthalocyanines bearing charged peripheral substituents occurs in solution, and thus, these molecules have been employed to study face-to-face heterodimer bound electrostatically. ${ }^{11}$ In these cases, there is an attraction between peripheral substituents of opposite charge and a hydrophobic interaction between the macrocycle cores.

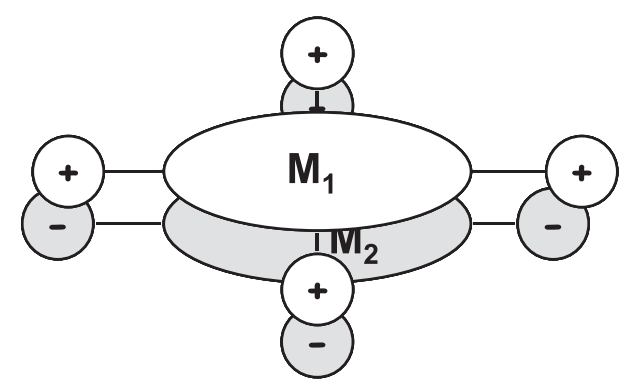

Figure 1. Schematic representation of a heterodimer formed by a tetracationic porphyrin and a tetraanionic phthalocyanine.

The synthetic cationic porphyrins employed in heterodimer formation are mainly limited to the mesotetrakis (N,N',N"-trimethylaminophenyl)porphyrin $\left(\mathrm{H}_{2} \mathrm{TAPP}\right)$ and specially meso-tetrakis(methylpyridiniumyl)porphyrin ( $\left.\mathrm{H}_{2} \mathrm{TMPyP}\right)$ ligands and their metallocomplexes (see Figure 2). ${ }^{12}$

Taking into account the importance of this type of heterodimers as models of the special pair in photosynthesis and the perspectives of their utilization as unidirectional electron transfer devices, ${ }^{13,14}$ we synthesized new cationic porphyrin derivatives and studied their general properties regarding heteroaggregation with anionic metallophthalocyanines in solution.

This new class of cationic porphyrins presents benzylic groups attached to the nitrogen atoms of the pyridyl residues located at the meso-porphyrin positions, resulting in the corresponding benzylpyridinium-yl cations surrounding the porphyrin macrocycle (see Figure 2).

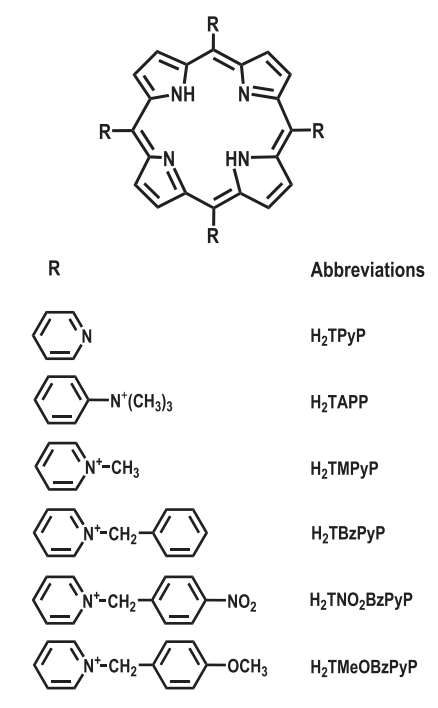

Figure 2. Structure of meso-substituted porphyrins.

These new benzylpyridinium-yl porphyrins are very attractive from the point of view of heterodimer formation, since they are cationic, show additional $\pi$ peripheric systems, and are more hydrophobic. These factors can modify the association process of macrocycles, altering formation equilibrium constants and spectroscopic/ photophysics properties of the heterocomplex.

\section{Experimental}

\section{Materials}

Spectroscopic grade DMSO was purchased from Merck and used as received. Tetrasodium salts of $\mathrm{Ni}(\mathrm{II})$ and $\mathrm{Cu}$ (II) 4,4',4",4"'-tetrasulfonated phthalocyanine were purchased from Aldrich and used as received. ZnTMPyP was synthesized according a previously reported methodology. ${ }^{15} \quad 5,10,15,20$-meso-tetrakis(benzylpyridinium-4-yl)porphyrin, $\mathbf{H}_{2}$ TBzPyP, 5, 10,15,20-mesotetrakis(p-nitro-benzylpyridinium-4-yl)porphyrin, $\mathbf{H}_{2} \mathbf{T N O}_{2} \mathbf{B z P y P}$, and 5,10,15,20-meso-tetrakis(p-methoxybenzylpyridinium-4-yl)porphyrin, $\mathbf{H}_{2}$ TMeOBzPyP, were synthesized by reacting $\mathrm{H}_{2}$ TPyP $\left(100 \mathrm{mg}, 1 \mathrm{mmol} \mathrm{dm}^{-3}\right)$ 
and the corresponding alkyl halide $\left(0.2 \mathrm{~mol} \mathrm{dm}^{-3}\right)$ in DMF, under stirring at $130{ }^{\circ} \mathrm{C}$. After reaction completion, the solvent was removed under reduced pressure. The crude product was washed several times with chloroform to remove excess of alkyl halide and filtered under vacuum. The porphyrin was then recristalized from methanol/ diethyl ether and recovered by vacuum filtration. ${ }^{16}$

The reaction between the free base $(100 \mathrm{mg}, 0.4 \mathrm{mmol}$

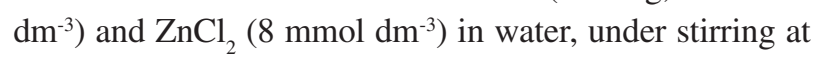
reflux temperature, produced the corresponding zinc complex. The reaction between the free base $(100 \mathrm{mg}$, $\left.0.2 \mathrm{mmol} \mathrm{dm}^{-3}\right)$ and $\mathrm{Na}_{2}\left[\mathrm{PdCl}_{4}\right]\left(0.8 \mathrm{mmol} \mathrm{dm}^{-3}\right)$ in water, under stirring at reflux temperature, produced the corresponding palladium complex. In both cases, the addition of a small volume of saturated $\mathrm{NaClO}_{4}$ aqueous solution causes the porphyrin precipitation. The solid was recovered by vacuum filtration. The porphyrin perchlorate salt could be metathesized with $\mathrm{LiCl}$ in $\mathrm{CH}_{3} \mathrm{CN}$ to form the water soluble $\mathrm{Cl}^{-}$salt.

All the porphyrins were characterized by elemental analysis and $\mathrm{H}^{1}-\mathrm{NMR}$. [ $\mathrm{H}_{2}$ TMPyP] $\mathrm{Tos}_{4} \cdot 8 \mathrm{H}_{2} \mathrm{O}(179 \mathrm{mg}$, $70 \%$ ): $\mathrm{C}_{72} \mathrm{H}_{66} \mathrm{~N}_{8} \mathrm{~S}_{4} \mathrm{O}_{12} \cdot 8 \mathrm{H}_{2} \mathrm{O}, \mathrm{MM}=1507 \mathrm{~g} \mathrm{~mol}^{-1}$. Elemental Analysis: Found C, 57.3; H, 5.49; N, 7.40 (Calc. for C, $57.4 ; \mathrm{H}, 5.44 ; \mathrm{N}, 7.43 \%) .{ }^{1} \mathrm{H}$ NMR $(300 \mathrm{MHz}, \delta$ ppm; dmso$\left.\mathrm{d}_{6,} 25^{\circ} \mathrm{C}\right): 9.45(8 \mathrm{H}, \mathrm{d}, o$-py), $9.17(8 \mathrm{H}, \mathrm{s}, \beta$-pyrrole), 8.95 (8H, d, $m$-py), $4.70\left(12 \mathrm{H}, \mathrm{s}, \mathrm{CH}_{3}\right),-3.12(2 \mathrm{H}, \mathrm{s}, \mathrm{NH})$.

$\left[\mathrm{H}_{2} \mathrm{TBzPyP}^{2} \mathrm{Cl}_{4} \cdot 9 \mathrm{H}_{2} \mathrm{O} \quad(174 \mathrm{mg}, \quad 80 \%)\right.$ : $\mathrm{C}_{68} \mathrm{H}_{54} \mathrm{~N}_{8} \mathrm{Cl}_{4} \cdot 9 \mathrm{H}_{2} \mathrm{O}, \mathrm{MM}=1286 \mathrm{~g} \mathrm{~mol}^{-1}$. Elemental Analysis: Found C, 63.5; H, 5.41; N, 8.83 (Calc. for C, 63.6; H, 5.60; N, 8.71\%). ${ }^{1} \mathrm{H}$ NMR (300 MHz, $\delta$ ppm; dmso$\left.\mathrm{d}_{6,} 25^{\circ} \mathrm{C}\right): 9.73(8 \mathrm{H}, \mathrm{d}, o$-py), $9.22(8 \mathrm{H}, \mathrm{s}, \beta$-pyrrole), 9.05 (8H, d, $m$-py), 7.92 (8H, d, $m$-benzylic), 7.61 (12H, m, oand $p$-benzylic), $6.27\left(8 \mathrm{H}, \mathrm{s}, \mathrm{CH}_{2}\right),-3.11(2 \mathrm{H}, \mathrm{s}, \mathrm{NH})$.

$\left[\mathrm{H}_{2} \mathrm{TNO}_{2} \mathrm{BzPyP}_{3} \mathrm{Br}_{4} .7 \mathrm{H}_{2} \mathrm{O} \quad(219 \mathrm{mg}, \quad 80 \%)\right.$ : $\mathrm{C}_{68} \mathrm{H}_{50} \mathrm{~N}_{12} \mathrm{Br}_{4} \mathrm{O}_{8} .7 \mathrm{H}_{2} \mathrm{O}, \mathrm{MM}=1616 \mathrm{~g} \mathrm{~mol}^{-1}$. Elemental Analysis: Found C, 50.9; H, 3.87; N, 10.2 (Calc. for C, 50.5; H, 3.96; N, 10.3\%). ${ }^{1} \mathrm{H}$ NMR (300 MHz, $\delta$ ppm; dmso$\left.\mathrm{d}_{6,} 25^{\circ} \mathrm{C}\right): 9.73$ (8H, d, o-py), 9.27 (8H, s, $\beta$-pyrrole), 9.09 (8H, d, $m$-py), 8.19 (8H, d, $m$-benzylic), 8.49 (8H, d, $o$ benzylic), $6.43\left(8 \mathrm{H}, \mathrm{s}, \mathrm{CH}_{2}\right),-3.09(2 \mathrm{H}, \mathrm{s}, \mathrm{NH})$.

$\left[\mathrm{H}_{2} \mathrm{TMeOBzPyP}_{\mathrm{Cl}} \cdot 10 \mathrm{H}_{2} \mathrm{O} \quad(145 \mathrm{mg}, 60 \%)\right.$ : $\mathrm{C}_{72} \mathrm{H}_{62} \mathrm{~N}_{8} \mathrm{O}_{4} \mathrm{Cl}_{4} \cdot 10 \mathrm{H}_{2} \mathrm{O}, \mathrm{MM}=1424 \mathrm{~g} \mathrm{~mol}^{-1}$. Elemental Analysis: Found C, 60.5; H, 5.78; N, 7.86 (Calc. for C, $60.7 ; \mathrm{H}, 5.76$; N, 7.86\%). ${ }^{1} \mathrm{H}$ NMR $(300 \mathrm{MHz}, \delta$ ppm; dmso$\left.\mathrm{d}_{6,} 25^{\circ} \mathrm{C}\right): 9.69$ (8H, d, $o$-py), $9.19(8 \mathrm{H}, \mathrm{s}, \beta$-pyrrole), 9.02 (8H, d, $m$-py), 7.90 (8H, d, $m$-benzylic), $7.18(8 \mathrm{H}, \mathrm{d}, o-$ benzylic), $6.19\left(8 \mathrm{H}, \mathrm{s}, \mathrm{CH}_{2}\right), 3.87\left(12 \mathrm{H}, \mathrm{s}, \mathrm{OCH}_{3}\right),-3.21$ (2H, s, NH).

[ZnTMPyP]Cl ${ }_{4} \cdot 10 \mathrm{H}_{2} \mathrm{O}$ (Yield: $57 \mathrm{mg}, 80 \%$ ): $\mathrm{ZnC}_{68} \mathrm{H}_{54} \mathrm{~N}_{8} \mathrm{Cl}_{4} \cdot 10 \mathrm{H}_{2} \mathrm{O}, \mathrm{MM}=1063.8 \mathrm{~g} \mathrm{~mol}^{-1}$. Elemental Analysis: Found C, 49.6; H, 5.25; N, 10.4 (Calc. for C,
49.6; H, 5.30; N, 10.5\%). ${ }^{1} \mathrm{H}$ NMR (300 MHz, $\delta$ ppm; dmso$\left.\mathrm{d}_{6}, 25{ }^{\circ} \mathrm{C}\right): 9.45$ (8H, d, $o$-py), 9.17 (8H, s, $\beta$-pyrrole), 8.95 (8H, d, m-py), $4.70\left(12 \mathrm{H}, \mathrm{s}, \mathrm{CH}_{3}\right)$.

$[\mathrm{ZnTBzPyP}] \mathrm{Cl}_{4} \cdot 4 \mathrm{H}_{2} \mathrm{O} \quad(88 \mathrm{mg}, \quad 90 \%)$ : $\mathrm{ZnC}_{68} \mathrm{H}_{52} \mathrm{~N}_{8} \mathrm{Cl}_{4} \cdot 4 \mathrm{H}_{2} \mathrm{O}, \mathrm{MM}=1259.9 \mathrm{~g} \mathrm{~mol}^{-1}$. Elemental Analysis: Found C, 64.9; H, 4.89; N, 8.86 (Calc. for C, 64.8; H, 4.81; N, 8.89\%). ${ }^{1} \mathrm{H}$ NMR (300 MHz, $\delta$ ppm; dmso$\left.\mathrm{d}_{6,} 25^{\circ} \mathrm{C}\right): 9.62$ (8H, d, $o$-py), 9.01 ( $8 \mathrm{H}, \mathrm{s}, \beta$-pyrrole), 8.92 (8H, d, $m$-py), 7.90 (8H, d, $m$-benzylic), 7.60 (12H, m, $o$ and $p$-benzylic), $6.25\left(8 \mathrm{H}, \mathrm{s}, \mathrm{CH}_{2}\right)$.

$\left[\mathrm{ZnTNO}_{2} \mathrm{BzPyP}_{\mathrm{Cl}} \cdot 4 \mathrm{H}_{2} \mathrm{O} \quad(77 \mathrm{mg}, \quad 85 \%)\right.$ : $\mathrm{ZnC}_{68} \mathrm{H}_{48} \mathrm{~N}_{12} \mathrm{O}_{8} \mathrm{Cl}_{4} \cdot 4 \mathrm{H}_{2} \mathrm{O}, \mathrm{MM}=1440.1 \mathrm{~g} \mathrm{~mol}^{-1}$. Elemental Analysis: Found C, 56.7; H, 4.06; N, 11.4 (Calc. for C $56.7 ; \mathrm{H}, 3.92 ; \mathrm{N}, 11.7 \%)$. ${ }^{1} \mathrm{H}$ NMR $(300 \mathrm{MHz}, \delta$ ppm; dmso$\left.\mathrm{d}_{6} 25^{\circ} \mathrm{C}\right): 9.66(8 \mathrm{H}, \mathrm{d}, o$-py), 9.07 ( $8 \mathrm{H}, \mathrm{s}, \beta$-pyrrole), 8.96 (8H, d, $m$-py), 8.18 (8H, d, $m$-benzylic), 8.48 (8H, d, $o$ benzylic), $6.42\left(8 \mathrm{H}, \mathrm{s}, \mathrm{CH}_{2}\right)$.

$[\mathrm{ZnTMeOBzPyP}] \mathrm{Cl}_{4} .7 \mathrm{H}_{2} \mathrm{O} \quad(81 \mathrm{mg}, \quad 80 \%)$ : $\mathrm{ZnC}_{72} \mathrm{H}_{60} \mathrm{~N}_{8} \mathrm{O}_{4} \mathrm{Cl}_{4} \cdot 7 \mathrm{H}_{2} \mathrm{O}, \mathrm{MM}=1441.7 \mathrm{~g} \mathrm{~mol}^{-1}$. Elemental Analysis: Found C, 59.9; H, 5.52; N, 6.55 (Calc. for C, 59.9 calc; H, 5.20; N, 7.07\%). ${ }^{1} \mathrm{H}$ NMR (300 MHz, $\delta$ ppm; dmso-d $\left._{6} 25^{\circ} \mathrm{C}\right): 9.54$ (8H, d, $o$-py), 9.00 (8H, s, $\beta$-pyrrole), 8.90 (8H, d, $m$-py), 7.86 (8H, d, $m$-benzylic), 7.18 (8H, d, $o$ benzylic), $6.13\left(8 \mathrm{H}, \mathrm{s}, \mathrm{CH}_{2}\right), 3.85\left(12 \mathrm{H}, \mathrm{s}, \mathrm{OCH}_{3}\right)$.

[PdTMPyP]Cl $4.12 \mathrm{H}_{2} \mathrm{O} \quad(68 \mathrm{mg}, \quad 90 \%)$ : $\mathrm{PdC}_{44} \mathrm{H}_{36} \mathrm{~N}_{8} \mathrm{Cl}_{4} \cdot 12 \mathrm{H}_{2} \mathrm{O}, \mathrm{MM}=1140.8 \mathrm{~g} \mathrm{~mol}^{-1}$. Elemental Analysis: Found C, 46.5; H, 4.90; N, 9.71 (Calc. for C, 46.3 ; H, 5.30; N, 9.80\%). ${ }^{1} \mathrm{H}$ NMR (300 MHz, $\delta$ ppm; dmso$\left.\mathrm{d}_{6,} 25^{\circ} \mathrm{C}\right): 9.47$ (8H, d, $o$-py), 9.10 ( $8 \mathrm{H}, \mathrm{s}, \beta$-pyrrole), 8.95 (8H, d, m-py), $4.71\left(12 \mathrm{H}, \mathrm{s}, \mathrm{CH}_{3}\right)$.

[PdTBzPyP]Cl $4.10 \mathrm{H}_{2} \mathrm{O} \quad(87 \mathrm{mg}, \quad 80 \%)$ : $\mathrm{PdC}_{68} \mathrm{H}_{52} \mathrm{~N}_{8} \mathrm{Cl}_{4} \cdot 10 \mathrm{H}_{2} \mathrm{O}, \mathrm{MM}=1409.1 \mathrm{~g} \mathrm{~mol}^{-1}$. Elemental Analysis: Found C, 57.9; H, 5.12; N 7.93 (Calc. for C, 57.9; H, 5.16; N, 7.95\%). ${ }^{1} \mathrm{H}$ NMR (300 MHz, $\delta$ ppm; dmso$\mathrm{d}_{6,} 25^{\circ} \mathrm{C}$ ): 9.63 (8H, d, $o$-py), 9.14 (8H, s, $\beta$-pyrrole), 9.00 (8H, d, $m$-py), 7.88 (8H, d, $m$-benzylic), 7.62 (12H, m, oand $p$-benzylic), $6.21\left(8 \mathrm{H}, \mathrm{s}, \mathrm{CH}_{2}\right)$.

\section{Methods}

Spectroscopic titrations were carried out by adding

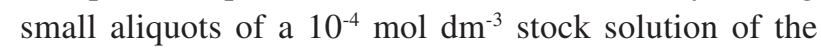
metalloporphyrin directly into a quartz cell containing $2.0 \mathrm{~cm}^{3}$ of a $10^{-6} \mathrm{~mol} \mathrm{dm} \mathrm{dm}^{-3}$ solution of metallophthalocyanine, or vice-versa. The measurements were performed at room temperature on a Beckman DU-70 spectrophotometer.

Heterodimers were characterized by determining the stoichiometry $(x)$ and formation equilibrium constants $\left(\mathrm{K}_{\mathrm{PI}}\right)$. The data from spectroscopic experiments were analyzed using Job's method. ${ }^{17}$ This method relies on the 
fact that the optical density of a solution containing a mixture of macrocycles, which do not react with on each other, is the sum of the absorption due to each one separately. Any deviation from this behavior after mixing small amounts of both solutions can be interpreted as evidence of complex formation. ${ }^{18}$ Job diagrams were obtained plotting $\mathrm{F}(\mathrm{x})$ against $\mathrm{x}$, since $\mathrm{x}$ is continuously varied during spectroscopic titration, according to the expression:

$F_{(x)}=\frac{A_{o b s}-\left(C_{P c} \varepsilon_{P_{c}}+C_{p} \varepsilon_{P}\right)}{\left(C_{P c}+C_{P}\right)}$

where $\mathrm{x}$ corresponds to the molar fraction of phthalocyanine, $\mathrm{A}_{\text {obs }}$ corresponds to the observed absorbance of the solution after each addition of titrant, $\mathrm{C}_{\mathrm{pc}}$ and $\mathrm{C}_{\mathrm{p}}$ correspond to the total concentration of phthalocyanine and porphyrin, respectively, and $\varepsilon_{\mathrm{Pc}}$ and $\varepsilon_{\mathrm{P}}$ are the molar absorptivities of the phthalocyanine and porphyrin, respectively, at a given wavelength. The stoichiometry of the formed aggregate corresponds to the maximum or minimum point found in the Job diagram. $\mathrm{K}_{\mathrm{PI}}$ values can be graphically assessed using the following expression: ${ }^{19}$

$$
\begin{aligned}
& \mathrm{K}_{\mathrm{Pl}}=\frac{2\left(1-\mathrm{R}_{1 / 2}\right)}{\left(\mathrm{C}_{\mathrm{P}}+\mathrm{C}_{\mathrm{Pc}}\right) \mathrm{R}_{1 / 2}^{2}} \text {, where } \\
& \mathrm{R}_{1 / 2}=\frac{2 \Delta_{1 / 2}}{\varepsilon_{\mathrm{P}}+\varepsilon_{\mathrm{PC}}+\varepsilon_{\mathrm{PPC}}} \text { and } \Delta_{1 / 2}=\mathrm{F}_{1 / 2}-\frac{1}{2}\left(\varepsilon_{\mathrm{PPc}}-\varepsilon_{\mathrm{P}}-\varepsilon_{\mathrm{Pc}}\right)
\end{aligned}
$$

\section{Results and Discussion}

\section{Synthesis}

Benzylic halides are well known alkylating agents. ${ }^{20}$ The reaction between $\mathrm{H}_{2}$ TPyP and an alkyl halide corresponds to a nucleophilic substitution reaction process involving the pyridine groups of the porphyrin. In the present study the reaction conditions were optimized in order to avoid other possible products: $i$ ) semialkylated porphyrins, which are compounds of an incomplete alkylation reaction; these porphyrins can be found with different degrees of non-alkylated pyridines (one to three); ii) N-Alkylated porphyrins, which are the products when the alkylation reaction takes place, not only at the pyridines, but also at the pyrrole nitrogen atoms of the porphyrin ring (see Figure 3).

${ }^{1} \mathrm{H}$ NMR analysis of purified samples of the free bases, evidenced that the absence of low frequency peaks

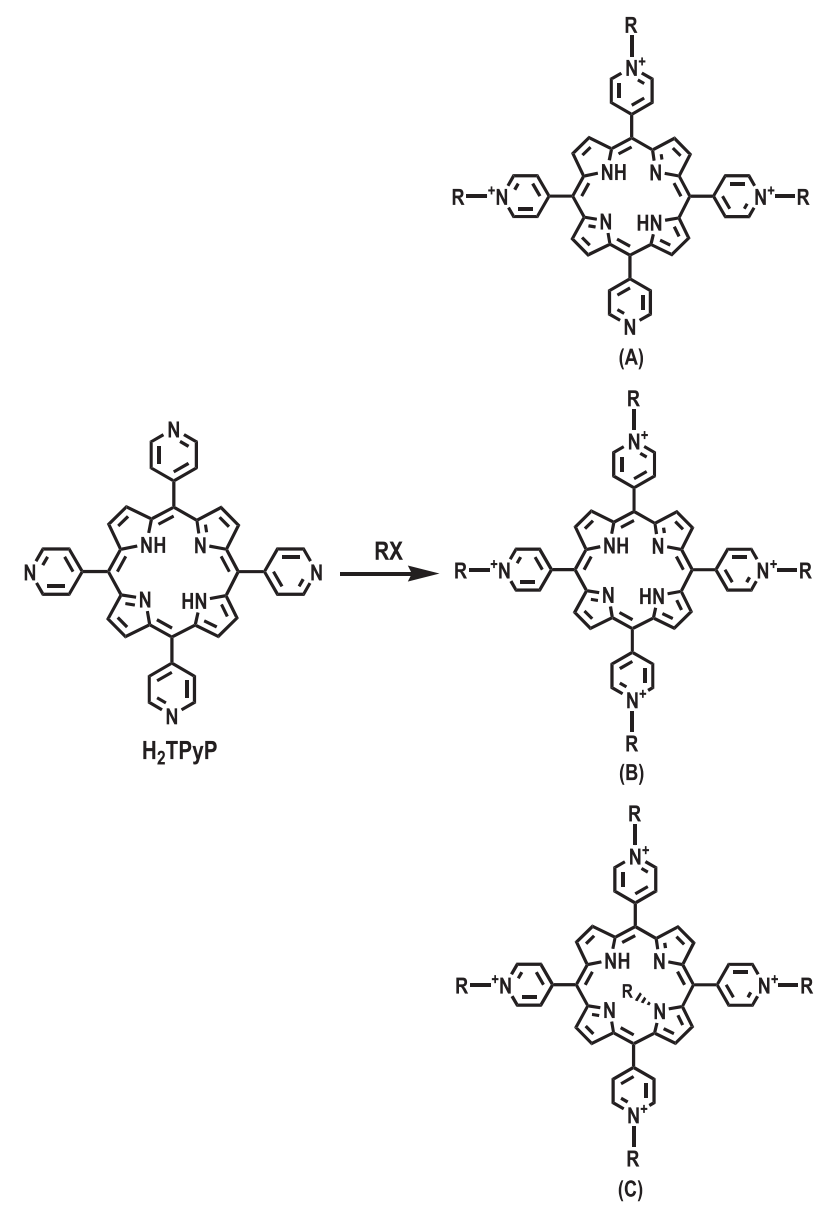

Figure 3. Pyridyl porphyrin alkylation products: (A) semi-alkylated porphyrin; (B) tetraalkylated porphyrin; and (C) N-pyrrole alkylated porphyrin.

corresponding to the 2,6 $(\delta 9.0)$ and 3,5 $(\delta$ 8.15) nonalkylated pyridine protons, excluding the presence of semialkylated porphyrin derivatives, and a sharp singlet in the $\delta-3.10$ region, showing that the integrity of the pyrrole protons was preserved, with no $\mathrm{N}$-alkylpirrole formation. A complete ${ }^{1} \mathrm{H}$ NMR assignment is presented in the experimental section for each derivative synthesized.

The metallation reactions were performed in water. In this case, both the ligand (free base porphyrin) and the metal ion source (inorganic salt) are soluble in the same solvent in a convenient extent, favoring the metal ion insertion into the porphyrin core. It is particularly true for the insertion of $\mathrm{Zn}(\mathrm{II})$, but for the metallation with $\mathrm{Pd}(\mathrm{II})$, only $\mathrm{H}_{2}$ TMPyP and $\mathrm{H}_{2}$ TBzPyP were conveniently metallated in reasonable yields and isolated with high purity. For $\mathrm{H}_{2} \mathrm{TNO}_{2} \mathrm{BzPyP}$ and $\mathrm{H}_{2} \mathrm{TMeOBzPyP}$ a precipitate formation was observed when the metal ion source was added to the reaction media. These precipitation products are insoluble in water, and slightly soluble in DMF. There is an incomplete metal insertion in these 
samples, as revealed by UV-Vis spectroscopy. The ligands $\mathrm{H}_{2} \mathrm{TNO}_{2} \mathrm{BzyP}$ and $\mathrm{H}_{2} \mathrm{TMeOBzPyP}$ are more hydrophobic and less water soluble than the parent cationic $\mathrm{H}_{2}$ TMPyP and $\mathrm{H}_{2}$ TBzPyP. Addition of $\mathrm{Na}_{2}\left[\mathrm{PdCl}_{4}\right]$ to the reaction medium, releases in water the $\left[\mathrm{PdCl}_{4}\right]^{2-}$ anion, which acts as a heavy counter ion, leading to both free base and $\mathrm{Pd}(\mathrm{II})$ porphyrin precipitation, prior to the complete porphyrin metallation process. In dilute conditions precipitation is negligible, but the metallation reaction does not occur in an appreciable extend, rendering the isolation of $\mathrm{Pd}(\mathrm{II})$ porphyrin difficult. Experiments were carried out in organic solvents (DMF, benzonitrile) and other metal sources employed, such as palladium bisbenzonitrile complex, but there was no convenient formation of the corresponding metalloporphyrin. Other strategies, such as the preparation of water soluble neutral palladium complexes, are in course in our laboratory.

\section{Zn(II)porphyrins/MPcTS systems $(M=C u, N i)$}

Figure 4 presents the spectral changes of a solution of the copper phthalocyanine in DMSO during the titration with a $\mathrm{Zn}$ (II)porphyrin solution. The spectral evolution after successive additions of porphyrin presents sharp isosbestic points, indicating an equilibrium in solution. All systems showed the same behavior.

As can be seen in Figure 4 (curve 2), when 1:1 stoichiometry is reached the resulting spectrum differs from the sum of those of the reactants. There is a decrease in intensity, a red shift and a broadening of the porphyrin Soret and phthalocyanine $\mathrm{Q}$ bands. A new broad absorption band in the $700 \mathrm{~nm}$ region can also be observed. These observations suggest marked perturbations in frontier molecular orbitals of the two precursors. Absorption band broadening and shifting are indicative of aggregate formation in porphyrin and phthalocyanine systems. ${ }^{21}$ Similar results observed by Gaspard ${ }^{22,23}$ and others ${ }^{19}$ were interpreted as evidence for the formation of heterodimers held face-to-face by electrostatic and van der Waals interactions, in equilibrium with starting monomers.

The data from the spectroscopic titration have been analyzed using Job's method. The Job diagram obtained for the ZnTMeOBzPyP/CuPcTS system at $\lambda=680 \mathrm{~nm}$, presented in Figure 5, consists of two straight lines intersecting at $\mathrm{x}=0.5$, thus indicating that only $1: 1$ heterodimer is formed. The same profile was observed when the Job diagram was constructed at different wavelengths (460 $\mathrm{nm}, 608 \mathrm{~nm}$ and $622 \mathrm{~nm})$. Similar diagrams were obtained for all $\mathrm{Zn}(\mathrm{II})$ porphyrins and metallophthalocyanines systems studied under these conditions. The association constants $\left(\mathrm{K}_{\mathrm{PP}}\right)$ obtained are presented in Table 1 .
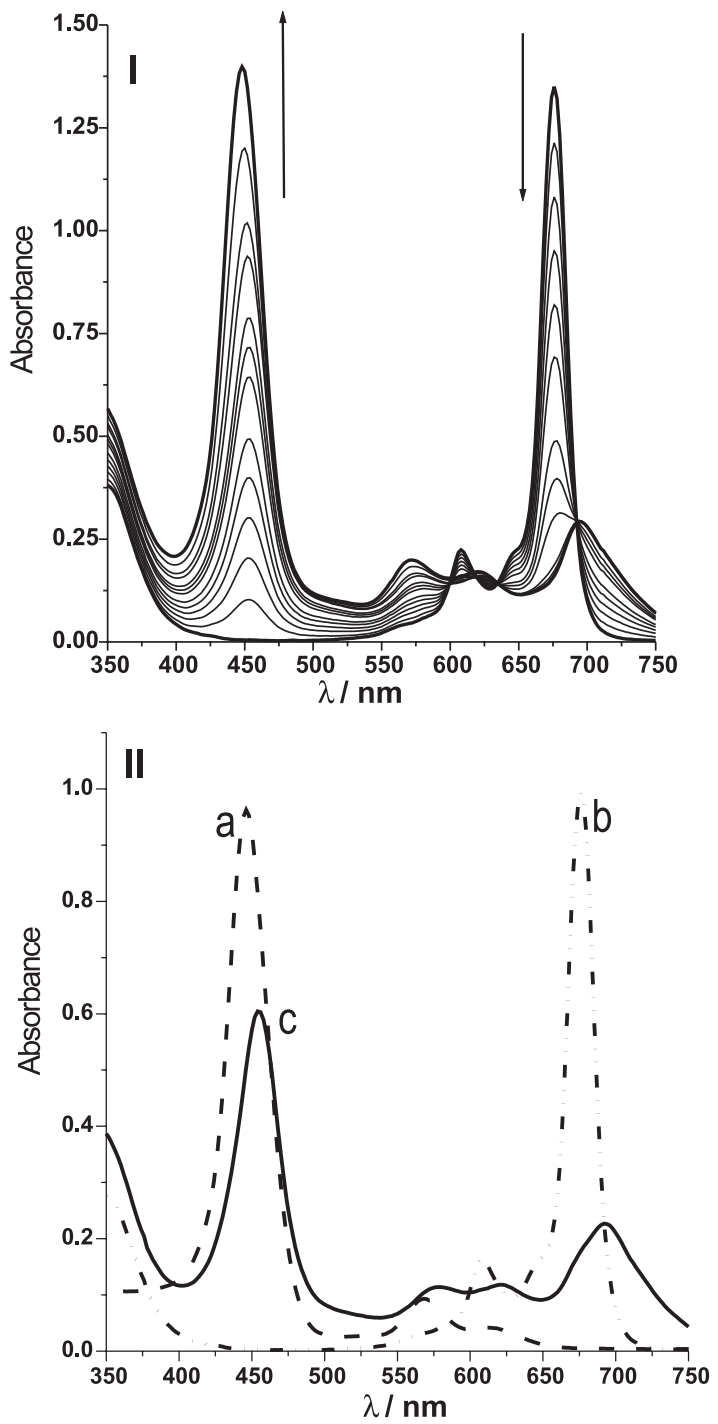

Figure 4. I- Spectral evolution during the titration of CuPcTS $6 \mu \mathrm{mol} \mathrm{dm}^{-3}$ by ZnTBzPyP $2 \times 10^{-4} \mathrm{~mol} \mathrm{dm}^{-3}$ in DMSO; II- UV-Vis absorption spectra of (a) $\mathrm{ZnTNO}_{2} \mathrm{BzPyP}$, (b) NiPcTS and (c) 1:1 mixture of $\mathrm{ZnTNO}_{2} \mathrm{BzPyP} / \mathrm{NiPcTS}$ in DMSO.

According the results presented in Table 1, it can be noted that $\mathrm{K}_{\mathrm{PI}}$ values obtained for the $\mathrm{Zn}$ (II)porphyrins/ NiPcTs heterodimers are about $50 \%$ smaller than those obtained for $\mathrm{Zn}$ (II)porphyrins/CuPcTs heterodimers.

It is well known that DMSO is a coordinating solvent with a high donor number on Gutmann's scale. ${ }^{24}$ The formation of mono-zincpyridinates on porphyrins moieties is very well documented. In solution, zincporphyrins will exist as a five coordinate square pyramidal species, with only one face available for heterodimer formation. ${ }^{12}$ Since the metal coordinated to the porphyrin macrocycle is always the same, these differences found in $\mathrm{K}_{\mathrm{PI}}$ values are related to the ability of axial coordination on the phthalocyanine moiety. 


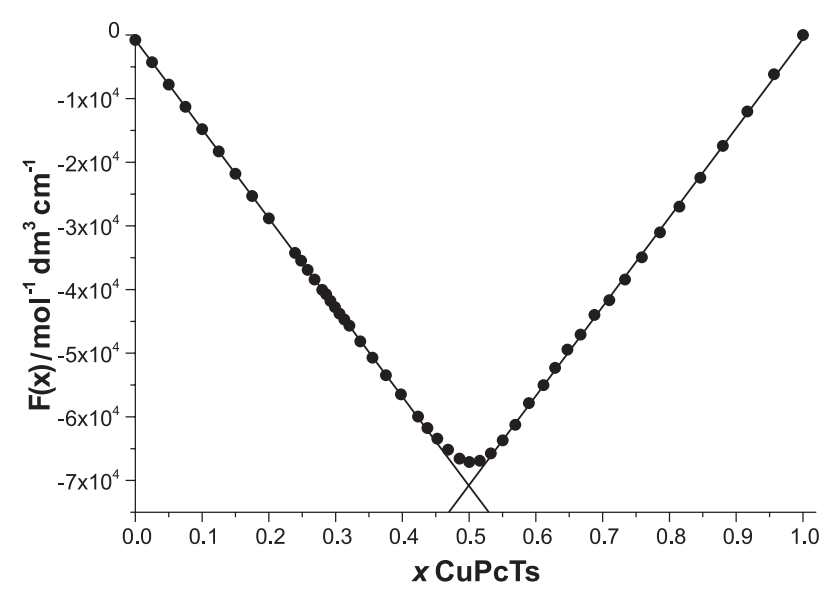

Figure 5. Job diagram for the ZnTMeOBzPyP/CuPcTS system in DMSO. $\lambda=680 \mathrm{~nm}$.

Table 1. $\mathrm{K}_{\mathrm{PI}}$ values to heterodimers $\mathrm{ZnP} / \mathrm{MPcTS}$ obtained in DMSO

\begin{tabular}{lll}
\hline Porphyrin & \multicolumn{2}{c}{$\mathrm{K}_{\mathrm{PI}}\left(\mathrm{mol}^{-1} \mathrm{dm}^{3}\right)$} \\
\cline { 2 - 3 } & $\mathrm{NiPcTS}$ & $\mathrm{CuPcTS}$ \\
\hline ZnTMPyP & $7.2 \times 10^{7}$ & $1.1 \times 10^{8}$ \\
ZnTBzPyP $_{\text {ZnTNO }}$ BzPyP & $6.6 \times 10^{7}$ & $1.2 \times 10^{8}$ \\
ZnTMeOBzPyP & $4.9 \times 10^{7}$ & $8.6 \times 10^{7}$ \\
\hline
\end{tabular}

Standard deviation $\pm 5 \%$.

An earlier study reported by Lipskier ${ }^{19}$ showed indirect evidences suggesting axial coordination to $\mathrm{Cu}$ and $\mathrm{Ni}$ by a DMSO molecule. Axially coordinated phthalocyanines, such as zinc porphyrins, are not planar, adopting a squarepyramidal geometry, where $\mathrm{Ni}-\mathrm{N}$ or $\mathrm{Cu}-\mathrm{N}$ presents an outof-plane distortion. In this case, it seems that $\mathrm{Ni}-\mathrm{N}$ is more distorted than $\mathrm{Cu}-\mathrm{N}$, which implies in smaller interaction with the porphyrin core, since the distortion by solvent coordination occurs in the opposite direction of heterodimer formation, thus diminishing the interaction between them.

The effect on the association constant caused by different $\mathrm{ZnP}$ structures is described bellow: $i$ ) the replacement of a methyl group by a simple unsubstituted benzyl group does not change significantly the $\mathrm{K}_{\mathrm{PI}}$ value, particularly in the case of the association with CuPcTS; ii) the presence of substituted benzyl groups containing nitro and methoxy residues causes a decrease in $\mathrm{K}_{\mathrm{PI}}$ values, but there is no significant difference between them.

In spite of the fact that the changes observed are not drastic, some interesting considerations can be done for this system. The existence of a benzylpyridinium type group attached to the porphyrin results, not only in the existence of additional $\pi$ systems at the porphyrin periphery, but also in an increase of the steric hindrance of the molecule. As can be observed in Figure $6^{25}$ the aryl group assumes a bent orientation, once it is bound via an $\mathrm{sp}^{3}$ orbital of the $\mathrm{CH}_{2}$ benzylic carbon. It means that the approximation of the anionic metallophthalocyanine becomes hindered and the contact distance between the pair increases. It must be mentioned that benzylic groups free rotate, and other dispositions can be assumed, but certainly the arrangement shown in Figure 6 has an important contribution in the association process. Interestingly the unsubstituted benzylic derivative (ZnTBzPyP) is little affected, and it can be due to the fact that in this case exist a convenient pairing, or mainly to the fact that the additional hydrophobic interactions furnished by benzyl groups counterbalance in part the unfavorable steric factors.

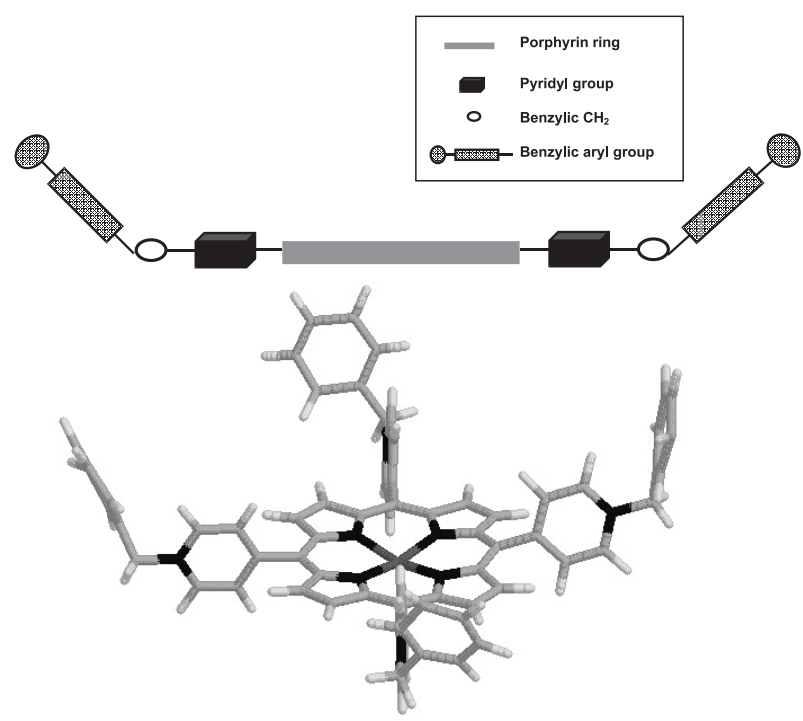

Figure 6. Structure obtained by molecular modeling (MNDO/software Gaussian 98) showing the disposition of the benzylic substituents in ZnTBzPyP. Note spatial crowding generated in one side of the porphyrin macrocycle. Inset: Schematic representation of a benzylic substituted porphyrin (front view).

$M_{1}$ porphyrins $/ M_{2} P c T S$ systems $\left(M_{1}=P d, H_{2} ; M_{2}=C u, N i\right)$

Figure 7 presents the spectral changes of a solution of NiPcTS in DMSO during the titration with a solution of PdTBzPyP.

In a similar way observed for the systems containing $\mathrm{Zn}$ (II)porphyrins, when a 1:1 stoichiometry is reached the resulting spectrum differs from the sum of those of the reactants. The Job diagram obtained to the PdTMPyP/ CuPcTS system at $\lambda=680 \mathrm{~nm}$ is presented in the Figure 8 .

In contrast to observed for the ZnP/MPcTS systems, the Job diagrams obtained for the PdP/MPcTS systems present three linear regimes and two intersection points in 


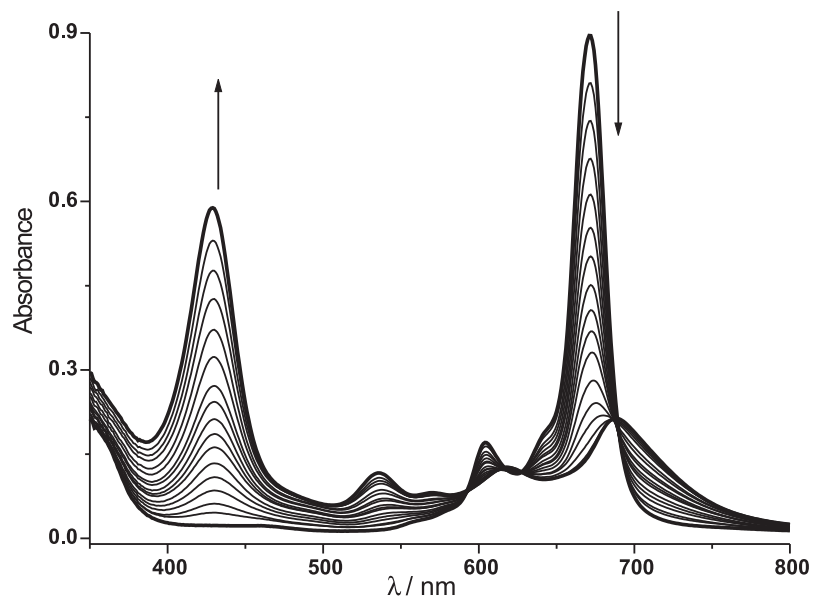

Figure 7. Spectral evolution during the titration of NiPcTS $6 \mu \mathrm{mol} \mathrm{dm}^{-3}$ by PdTBzPyP $2 \times 10^{-4} \mathrm{~mol} \mathrm{dm}^{-3}$ in DMSO.

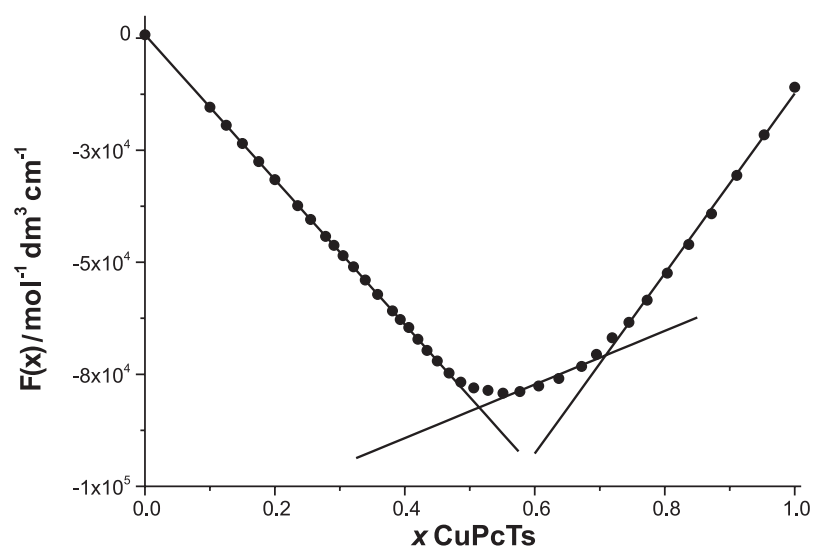

Figure 8. Job diagram for the PdTMPyP/CuPcTS system in DMSO. $\lambda=680 \mathrm{~nm}$.

$\mathrm{x}=0.5$ and 0.7 . This behavior suggests that two different species are formed in solution, one with a 1:1 stoichiometry $(\mathrm{PdP} / \mathrm{MPc})$ and the other with a 1:2 stoichiometry (PdP/ $\left.\mathrm{MPc}_{2}\right) .{ }^{17}$ The association constants $\left(\mathrm{K}_{\mathrm{PI}}\right)$ obtained for these systems are presented in Table 2 . The different profiles of the Job diagrams obtained for the heterodimer ZnTMPyP/ CuPcTS and heterotrimer PdTMPyP/(CuPcTS $)_{2}$ can be observed in Figure 9.

As observed for the $\mathrm{Zn}(\mathrm{II}) \mathrm{P} / \mathrm{MPcTS}$ systems, the $\mathrm{K}_{\mathrm{PI}}$ values obtained for the $\mathrm{Pd}(\mathrm{II})$ porphyrins/NiPcTs heterodimers are smaller when compared to those obtained for the Pd(II)porphyrins/CuPcTs heterodimers. Same behavior is observed for the heterotrimers. The $\mathrm{K}_{\mathrm{PI}}$ values for the heterodimer formation is similar for both PdTMPyP/ MPcTS and PdTBzPyP/MPcTS systems as already seen for the $\mathrm{ZnP} / \mathrm{MPcTS}$ systems.

The experimental data obtained using the $\mathrm{Pd}(\mathrm{II})$ porphyrins indicate that the stoichiometry of the aggregate depends on the central metal complexed to the macrocycle. This dependence can be explained taking into account the ability of the central metal axially to bind a solvent molecule.
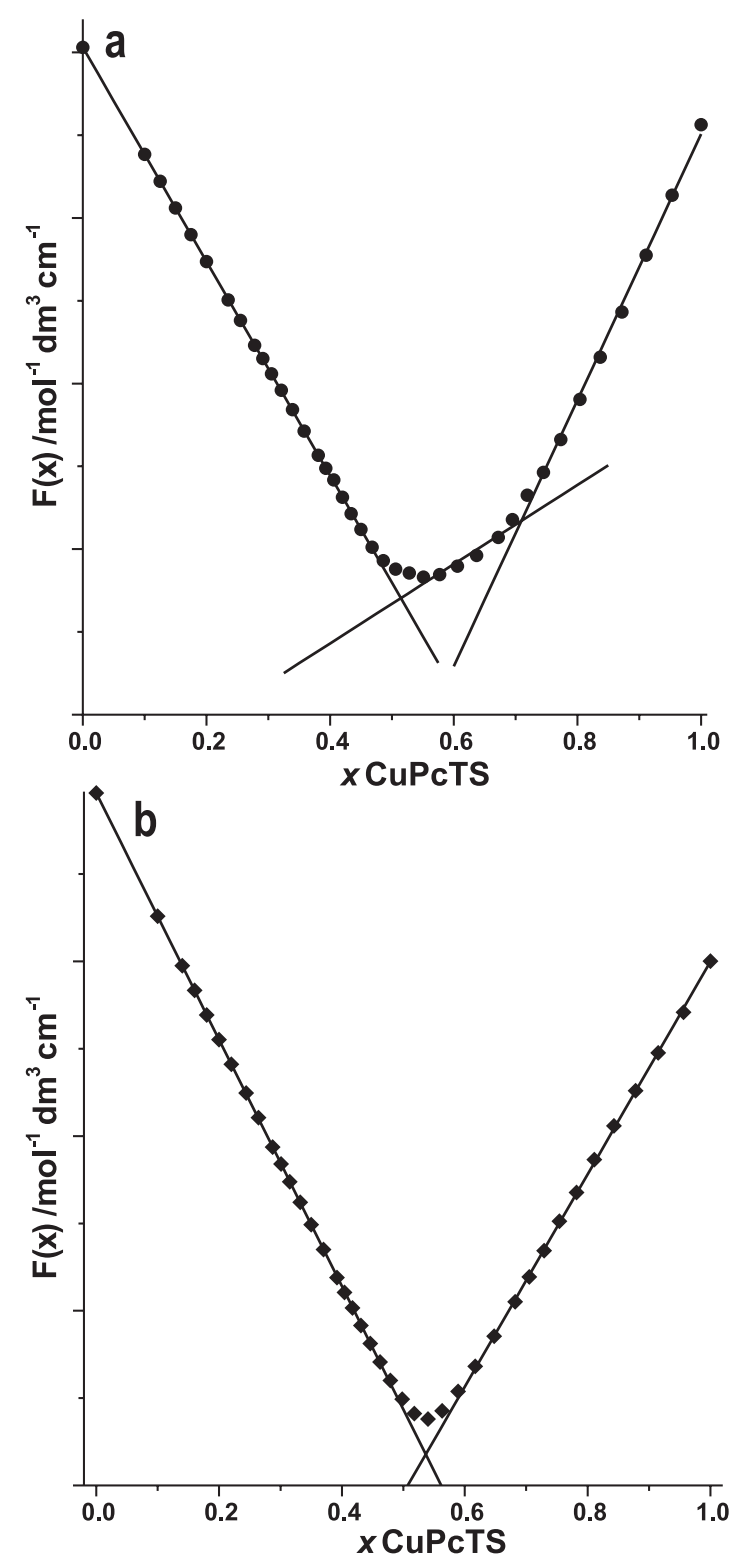

Figure 9. Job diagram for the (a) PdTMPyP/CuPcTS system; and for the (b) ZnTMPyP/CuPcTS system in DMSO. $\lambda=680 \mathrm{~nm}$.

Table 2. $\mathrm{K}_{\mathrm{PI}}$ values to heterodimers PdP/MPcTS and heterotrimers $\mathrm{PdP} / \mathrm{MPcTS}_{2}$ obtained in DMSO

\begin{tabular}{|c|c|c|c|c|}
\hline \multirow{3}{*}{ Porphyrin } & \multicolumn{4}{|c|}{${ }^{\mathrm{a}} \mathrm{K}_{\mathrm{PI}}$} \\
\hline & \multicolumn{2}{|c|}{ CuPcTS } & \multicolumn{2}{|c|}{ NiPcTS } \\
\hline & $\mathrm{P}: \mathrm{Pc}$ & $\mathrm{P}: \mathrm{Pc}_{2}$ & $\mathrm{P}: \mathrm{Pc}$ & $\mathrm{P}: \mathrm{Pc}_{2}$ \\
\hline PdTMPуP & $6.4 \times 10^{7}$ & $9.6 \times 10^{16}$ & $4.4 \times 10^{7}$ & $1.9 \times 10^{16}$ \\
\hline PdTBzPyP & $6.0 \times 10^{7}$ & $3.5 \times 10^{16}$ & $4.6 \times 10^{7}$ & $1.5 \times 10^{16}$ \\
\hline
\end{tabular}


In DMSO solution, Zn(II)porphyrins can bind axially one solvent molecule. There are evidences that the same occurs with the phthalocyanines. So, in this case, only one face of the macrocycle is available to the face-to-face contact (approximation); a solvent molecule hinders the other face.

Pd(II)porphyrins are known to adopt a square-planar geometry.26 Since the Pd(II)porphyrin remains square planar in solution, both faces of the macrocycle are available to the phthalocyanine approximation, allowing the heterotrimer formation.

\section{Conclusions}

This study has presented the synthesis of new cationic porphyrin/metalloporphyrin derivatives and the association behavior with anionic phthalocyanines. The reaction conditions between $\mathrm{H}_{2}$ TPyP and the corresponding benzylic halides were optimized in order to obtain preferentially the tetraalkylated products minimizing competitive reactions that can lead to a semi and N-pyrrol alkylated compounds. The corresponding $\mathrm{Zn}$ (II) metal complexes were easily obtained reacting the free bases and a convenient metal ion source in water. It was not possible obtain in satisfactory yield and purity the $\mathrm{Pd}$ (II) complexes of $\mathrm{H}_{2} \mathrm{TMeOBzPyP}$ and $\mathrm{H}_{2} \mathrm{TNO}_{2} \mathrm{BzPyP}$ ligands. The $\left[\mathrm{PdCl}_{4}\right]^{2-}$ anion acts as a heavy counter-ion in the presence of these more hydrophobic ligands and a precipitation process takes place, avoiding the complete metallation reaction. Regarding the association processes the results obtained clearly indicates that (i) the aggregate stoichiometry can be controlled by changing the nature of central metal; (ii) the magnitude of association between the monomers can be altered by changing the peripheral substituents, and (iii) the hetrodimers display optical properties completely different from the starting monomers, suggesting that the macrocycles are strongly coupled. This means that in spite the fact the association between these tetrapyrrolic compounds is mainly governed by electrostatic attraction, the properties of the pair can be controlled by steric factors furnished by axial coordination and/or ligand structure. A detailed photophysical characterization of these heteroaggregates is under investigation.

\section{Acknowledgements}

The authors wish to thank Prof. F.R. Ornellas and Dr. L. Tsuyoshi for molecular modeling calculations and gratefully acknowledge financial support from FAPESP (Fundação de Amparo à Pesquisa do Estado de São Paulo, 00/03382-1 and 00/11429-8).

\section{References}

1. Voet, D.; Voet, J.G.; Biochemistry, $2^{\text {nd }}$ ed., Wiley: New York, 1990.

2. Brunori M.; Hemoglobin and Myoglobin in Their Reactions with Ligands, North Holland Publishers: Amsterdam, 1971.

3. Wasielewski, M. R.; Chem. Rev. 1992, 92, 435.

4. Deisenhofer, J.; Norris, J.R.; The Photosynthetic Reaction Center, Academic Press: San Diego, 1993, vol. 1 and 2.

5. Gust, D.; Moore, T.; Top. Curr. Chem. 1991, 159, 103.

6. Ward, M. D.; Chem, Soc. Review 1997, 26, 365.

7. Sakata, Y.; Imahori, H.; Tsue, H.; Higashida, S.; Akuyama, T.; Yoshizawa, E.; Aoki, M.; Yamada, K.; Hagigawa, K.; Tamiguchi, S.; Okada, T.; Pure Appl. Chem. 1997, 69, 1951.

8. Souza, F.; Deviprasad, G. R.; Rahman, M. S.; Chi, J.; Inorg. Chem. 1999, 38, 2157.

9. Ojadi, E.; Selzer, R.; Linschitz, H.; J. Am. Chem. Soc. 1985, 107, 7783.

10. Schneider, H-J.; Wang, M.; J. Org. Chem. 1994, 59, 7464.

11. Gaspard, S.; Giannotti, C.; Maillard, P.; Schaeffer, C.; TranThi, T-H.; J. Chem. Soc., Chem. Commun.1986, 1239.

12. Tran-Thi, T-H.; Coord. Chem. Rev. 1997, 160, 53.

13. Schaafsma, T. J.; Savenije, T. J., Koehorst, R. B. M; Vergeldt F. J.; Wienke, J.; J. Lumin. 1997, 72-74, 81.

14. Savenije, T. J., Koehorst, R. B. M; Schaafsma, T. J.; Chem. Phys. Lett. 1995, 244, 363.

15. Azzellini, G. C.; Ph.D. Thesis, Universidade de São Paulo, Brazil, 1992.

16. Liegel, R. M.; Ph.D. Thesis, Universidade de São Paulo, Brazil, 2002.

17. Hill, Z. D.; MacCarthy, P.; J. Chem. Educ. 1986, 63:2, 162.

18. Connors, K; Binding Constants, John Wiley: New York, 1987.

19. Lipskier, J. F.; Tran-Thi, T.-H.; Inorg. Chem. 1993, 32, 722.

20. Sykes, P.; Guidebook to Mechanism in Organic Chemistry, Longman Scientific \& Technical, John Wiley: New York, 1986.

21. Geiger, D.; Kelly, C.A.; Inorg. Chim. Acta 1998, 137.

22. Tran-Thi, T-H.; Gaspard, S; Chem. Phys. Lett.1998, 148, 327.

23. Tran-Thi, T-H; Desforge, C.; Thiec, C.; Gaspard, S.; J. Phys. Chem. 1989, 93, 1226.

24. V. Gutmann, V.; Coordination Chemistry in Non-Aqueous Solutions, Springer-Verlag: New York, 1968.

25. The Molecular Modeling of the studied porphyrins were kindly performed by Prof. F.R. Ornellas and Dr. L. Tsuyoshi, using semi-empirical MNDO calculations.

26. M. Gouterman, M.; The Porphyrins, Academic Press: New York, 1978.

Received: January 20, 2003

Published on the web: August 12, 2003

FAPESP helped in meeting the publication costs of this article. 